\title{
Midstream AsSeTS: \\ Issues Emerging from a Changing Business
}

\section{J. JAY PARK}

This article examines emerging trends in the ownership and financing of midstream assets. It reviews some of the issues arising as a result of these trends under the current standard terms of construction ownership and operation agreements, and offers suggestions for how these terms can be tailored to address these issues.
Le présent article porte sur les tendances émergentes en matière de propriété et de financement des actifs dits de "midstream" (collecte, traitement du gaz). Il examine certaines des questions qui en résultent aux termes des contrats de construction et des accords d'exploitation actuels; et suggère plusieurs façons d'en modifier les clauses en conséquence.

\section{TABLE OF CONTENTS}

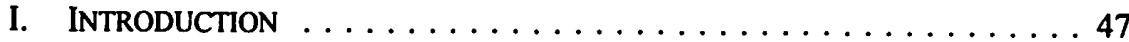

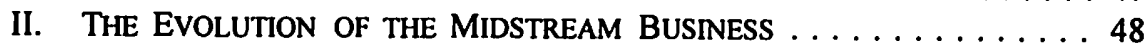

III. THE Two Principal Alternative Structures $\ldots \ldots \ldots \ldots \ldots .50$

A. Financing Party Transaction Structures $\ldots \ldots \ldots \ldots .51$

B. MIDSTREAM COMPANY

TRANSACTION STRUCTURES $\ldots \ldots \ldots \ldots \ldots \ldots \ldots 54$

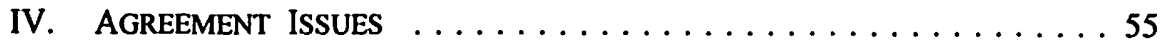

A. ASSET PURChASE AGREEMENT

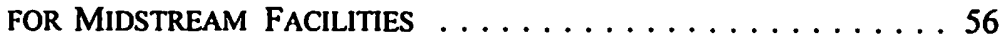

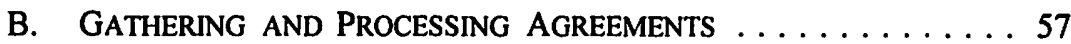

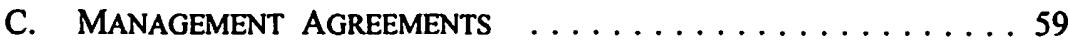

D. CO\&O AGREEMENTS .................. 59

E. LENDER ARRANGEMENTS $\ldots \ldots \ldots \ldots \ldots \ldots \ldots \ldots \ldots 72$

F. THE MISSING CO\&O AGREEMENT $\ldots \ldots \ldots \ldots \ldots \ldots 72$

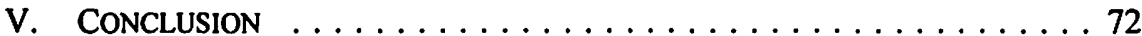

\section{INTRODUCTION}

The Canadian natural gas business has seen remarkable change since 1985 and the advent of deregulation. Indeed, a natural gas producer from the early eighties would hardly recognize that business as it is conducted today. Negotiated prices, open access to pipelines and downstream markets, the emergence of energy marketers, and pipeline expansion have all altered the conduct of the natural gas business in fundamental ways. However, at its most basic physical level, the gas business is unchanged; companies explore for, produce, gather, and process natural gas for sale.

More recently, the kinds of systemic changes that have affected so-called "downstream" activities (the sale, distribution, and transportation of gas near the burner tip) are now moving "upstream," closer to the wellhead. Many companies are now taking a different view of their investments and activities for the gathering and 
processing of gas, the so-called "midstream," and new ownership structures are becoming common. Some of these new arrangements are in the nature of structured financings, where ownership of midstream facilities changes, but the producer retains operational control. The other type of arrangement is related to the emergence in Canada of a new kind of business entity, a midstream company, that acquires and operates midstream facilities.

The purpose of this article is to describe some of the causes of change in the Canadian midstream business and the types of midstream asset transactions that are occurring, whether they involve structured financing arrangements or midstream companies. This article will also address the issues involved in transactions of these kinds, especially as they relate to gathering and processing agreements as well as construction, ownership, and operation agreements that govern midstream activities.

\section{The Evolution of THE Midstream Business}

Traditionally, producers of gas build the gathering and processing facilities required to produce gas from the lands they own. There are a number of reasons for this. First, producers want to control plant access in the geographic area where their lands are located. This is especially true during the exploration phase when competitive pressures lead producers to want to control development in the area. Secondly, the existence of exploration and development prospects permit the producers to be able to sustain any production growth that might be required to keep the facilities at full capacity. Thirdly, many producers believe that they are in the best position to ensure low operating costs for the facilities.

The experience in the United States has been quite different from that in Canada. Canadian producers have almost invariably built their own gathering and processing facilities to connect to the main transportation pipelines as though these midstream facilities were extensions of the downhole and surface facilities required to produce gas. In the United States, interstate pipeline companies built many of the gathering and processing facilities as though they were upstream extensicins of their pipelines. The deregulation process in the United States and the restructuring of long-haul pipeline tariffs led the interstate pipeline companies to divest most of their gathering and processing facilities. Also, those American producers who built their own gathering and processing facilities often chose to sell their interest in underutilized midstream facilities or in facilities where their gas represented the minority of the equity gas being processed in the facility.

The contrast between the Canadian and American situations is apparent when the statistics regarding facility ownership is examined. Until recently in Canada, virtually all midstream facilities were owned by producers. In the United States, less than half of all midstream facilities are owned by producers.

However, some of the pressures and circumstances that led to the ownership structure in the United States are occurring in Canada. Development of the Western Canada Sedimentary Basin is approaching the age of the American basins at the time the 
midstream business became prevalent there. Underutilized midstream facilities are more common in Canada now than a decade ago. Also, most American jurisdictions have access to multiple intrastate and interstate pipelines such that American producers have fewer competitive concerns. They know that there are a number of options for the transportation of their gas. Thus, the need for control over facilities is less apparent in the United States. The Canadian situation is different, but is changing with the advent of Alliance Pipeline, which will provide transportation options to producers.'

There are a number of reasons why a producer may choose to divest itself of its interest in midstream assets. Gathering and processing facilities are very expensive, and substantial capital commitments are required to build or expand them. If a producer divests its interest in midstream assets, it is able to re-deploy this capital for exploration and development activities, the principal focus of most producing companies. The desire to do this may be particularly strong where insufficient capital is available from traditional sources. In some cases, the value of the midstream assets is significant, and a divestment permits a producer to realize that value. Another advantage that a producer may be able to obtain is the establishment of long-term fee certainty through a processing agreement with a midstream participant.

For the past five years, many have said that the time is ripe for Canadian producers to change their approach to the ownership of midstream assets. Departing the midstream business would permit producers to focus on their strengths in exploring for and producing oil and gas, rather than devoting capital to midstream assets. In the last two years, producers have begun to pursue this approach in significant numbers and it appears that the desire to move in this direction is accelerating. There are over 700 gas processing facilities in Alberta with a "nameplate" capacity of $25 \mathrm{Bcf}$ per day. Approximately 350 of these gas plants have a capacity of less than $12.5 \mathrm{MMcf}$ per day. It has been estimated that the utilization rate of these facilities is approximately 55 percent, and that this represents an inefficient use of $\$ 3$ to $\$ 5$ billion of capital. Consolidation of underutilized facilities is a real opportunity in Canada, and, in the last two years, midstream companies have increased their holdings of Canadian midstream assets to approximately 20 percent. $^{2}$

The role of midstream companies has also gained increased acceptance recently. There is growing recognition that a company devoted to maximizing the income of gathering and processing facilities is a more suitable owner of such facilities than a producer whose principal focus is exploration and production. Producers are also becoming more comfortable with having their gas processed by a midstream company or co-owning a facility with a midstream company. This is in part because the companies are not leasehold competitors in the area and because their focus is on

I The history of the midstream business in the United States is based on comments by S. Woodward, "Midstream Purchases and Other Transaction Structures" (Insight Information Co. Seminar, "Effectively Managing Investments in Gas Processing Assets," 28-29 January 1999) [unpublished]. 
enhancing facility revenue and reducing facility costs, with the attendant benefits to all owners and users of the facility. A midstream company is also willing to spend capital to bring additional reserves into the facility. All of these developments have led to a new focus on the business and agreement issues associated with midstream transactions.

\section{The Two Principal Alternative Structures}

There are two quite different approaches that Canadian producers are adopting when implementing this strategic shift. Some producers are entering into financing arrangements for midstream assets with a financing entity that does not assume operational control of the facilities (a "Financing Party"). Other producers are involving companies that focus on the ownership and operation of midstream facilities that build or acquire the assets and operate them (a "Midstream Company"). For the purposes of this article, Financing Parties and Midstream Companies will be referred to collectively as "midstream entities." Each of these fundamental types of structures still permit a great deal of creativity in the kind of transaction that can be done, as will be described below. However, there are still certain key distinctions between these two structures.

It should not be forgotten that many producers continue to use traditional financing arrangements to fund their capital needs. These traditional financing arrangements involve a loan to the producer by a bank or other lending institution with fixed charge security on the midstream assets. These arrangements are neither new nor innovative and will not be discussed in this article.

When a Financing Party is involved in the midstream transaction, the producer will retain control of the assets. Also, the transaction is structured in such a way as to transfer little risk to the Financing Party. This is not unusual because the Financing Party is typically a bank or near-bank lender and is not in the business of assuming the risks of the oil and gas industry. For related reasons, the term of the arrangement with the Financing Party is usually for a medium term of three to five years. The transaction may be an on-balance sheet financing or an off-balance sheet financing, depending on the structure that is adopted.

A Midstream Company typically owns and operates the gathering and processing facilities. It will assume some measure of risk for throughput, capital cost, operating cost, commodity price, capacity, and environmental issues, but the extent to which it is prepared to accept those risks and the compensation that it requires in order to do so are a matter of negotiation. The term of a transaction with a Midstream Company is longer than with a Financing Party and in many cases is for the entire remaining life of the midstream assets.

While there have been some examples of Midstream Companies constructing new facilities, it is more common to see acquisitions of existing facilities by Midstream Companies. Midstream Companies are risk averse (though not as risk averse as banks), and the construction of new facilities where the full production potential of the surrounding lands is unknown sometimes presents greater risks than they are willing to bear. 


\section{A. Financing Party Transaction Structures}

There are a number of different structures used by Financing Parties. Some are quite unique and innovative, occasionally involving a combination of some of the structures described below. The following are the most common structures that are currently being utilized for midstream assets.

For each of the following structures, the producer either sells its interest in the facility to the Financing Party and then enters into the arrangement described below, or the Financing Party constructs the facility and enters into the arrangement. One of the key issues, particularly from the point of view of tax treatment of the transaction, is whether it is characterized as a lease, a purchase, or a loan. This characterization determines whether payment made under the arrangement is a rent, the payment of a purchase price, or the payment of principal and interest.

\section{Capital Lease}

In a capital lease arrangement, the Financing Party leases the facility to the producer. In many cases, the lease is accompanied by a purchase option in favour of the producer, which may be at a "bargain" price in the capital lease situation. In a capital lease, from the lessee's perspective, substantially all of the benefits and risks of ownership of the facilities are transferred to the lessee. If the monthly rental payments paid by the lessee are sufficient to amortize the principal and interest amounts due on a notional loan equal to the purchase price, then the transaction will be characterized as a capital lease. The Financing Party is deemed to have a disposition of the facility, with the potential for recapture or capital gain, and is taxable on the notional interest received. The producer has acquired the facility and can deduct the capital cost allowance associated with its purchase. It can also deduct the "notional" interest paid as part of the rental payment.

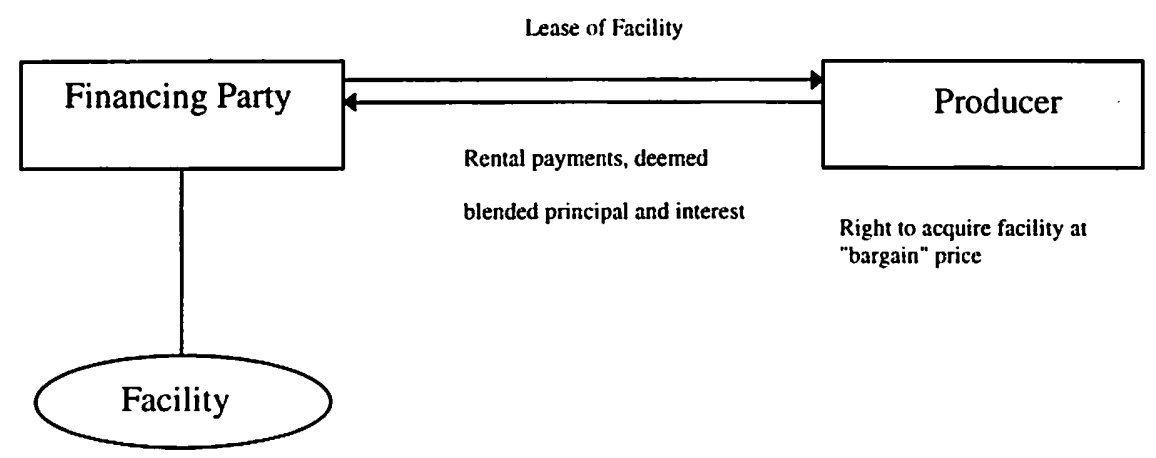

\section{OPERATING LeASE}

An operating lease involves an off-balance sheet type of financing for the producer. The Financing Party is treated as the owner of the facility and can claim capital cost allowance, and the rental payments are income. The producer can deduct the full 
amount of lease payments in calculating its income. The producer may have a right to repurchase the facility at a later date, but at a price which represents the current estimate of the fair market value of the facility at that time. Another variation of this structure involves a joint election by the producer and the Financing Party under section 16.1 of the Income Tax $\mathrm{Act}^{3}{ }^{3}$ which permits the producer to deduct capital cost allowance as though it owns the facility even though it does not. ${ }^{4}$

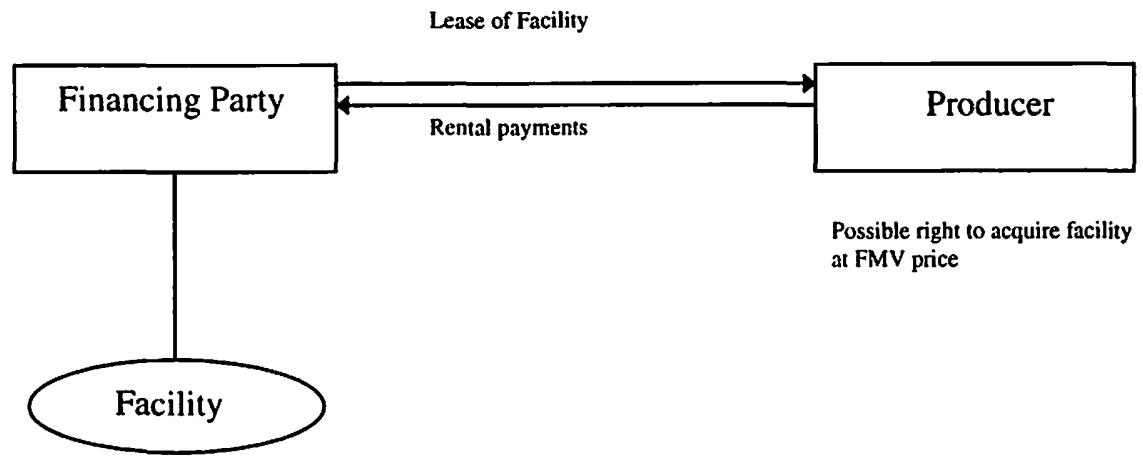

\section{Processing fee ARRANGement}

Under a processing fee arrangement, the Financing Party enters into a processing agreement with the producer pursuant to which the producer pays a fee for the processing of gas. The producer continues to operate the facility under a contract operating agreement and charges an operating fee. There is usually a right to acquire the facility at a later date at a price equal to the current estimate of the facility's future fair market value. The key attributes are similar to the operating lease situation, but the Financing Party is taxable on the processing fees and deducts the contract operating fees. Conversely, the producer is taxable on the contract operating fees but deducts the processing fees in calculating its income.

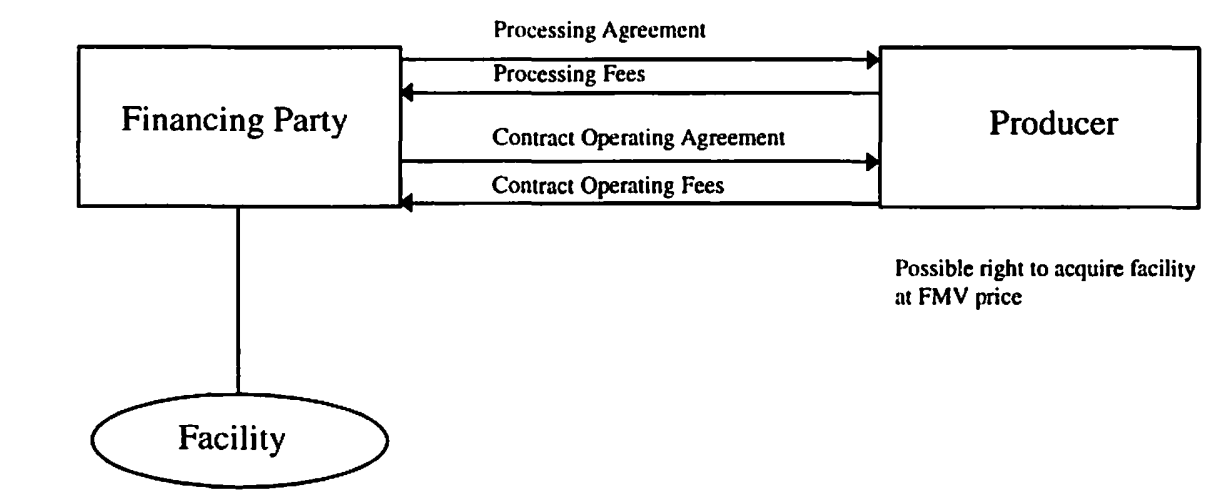

The tax implications of the structures described here are beyond the scope of this article. For further detail on these issues, see R.J. Iverach, Q.C., "Tax Issues in Structuring Gas Process Arrangements" (Insight Information Co. Seminar, "Effectively Managing Investments in Gas Processing Assets," 28-29 January 1999) [unpublished]. 


\section{INCOME TRUSTS AND LIMITED PARTNERSHIPS}

While generally most prevalent in connection with the acquisition of oil and gas producing interests, income trusts have also been used in connection with midstream asset transactions. In the typical situation, an operating company owns or acquires the midstream facility. All of the shares of the operating company are owned by the trust. The trust raises funds by means of a public offering of the units of the trust, and the proceeds of that public offering are used to fund the construction or acquisition of the midstream facility. The trust loans these funds to the operating company so that the interest costs of the loan shelter the income from the facility. Income from the operating company is paid to the unitholders of the trust, who have a freely trading security with a flow-through of facility income.

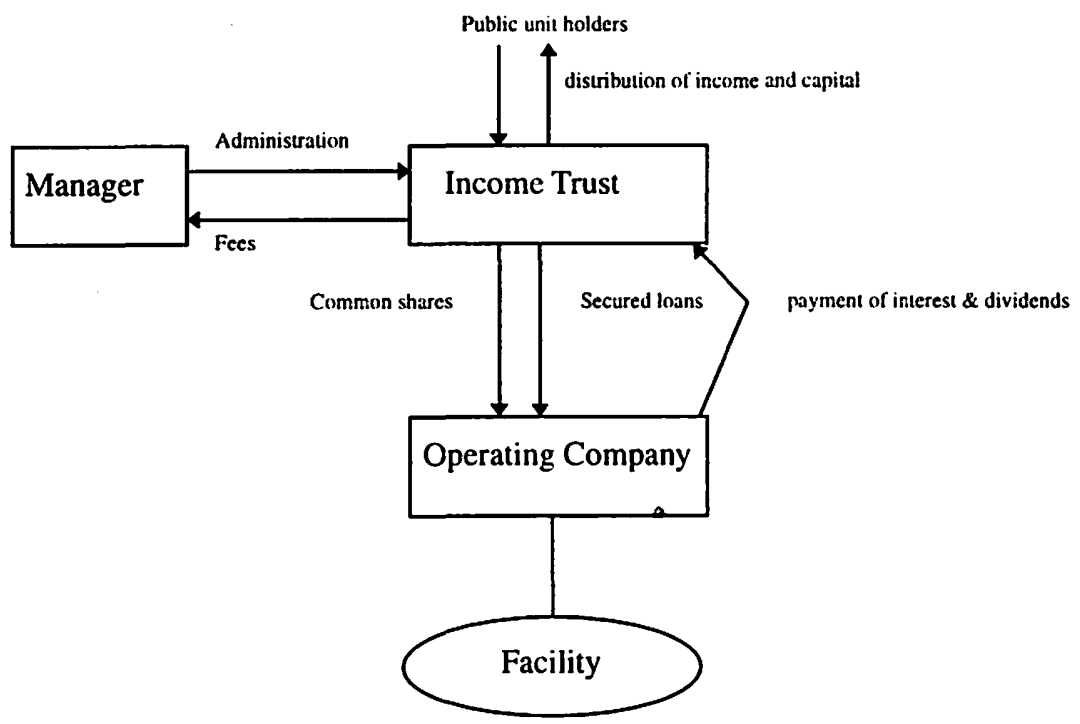

There are also variations of this structure using a commercial trust, which may have some tax advantages in certain situations.

Limited partnerships have also been used in some midstream transactions with a similar effect. A typical structure is as follows:

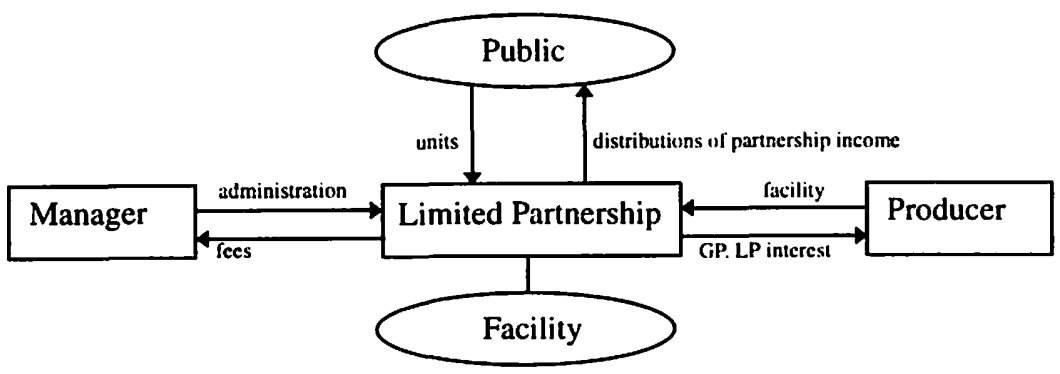




\section{SYNTHETIC LEASE}

A "synthetic lease" is a financing arrangement which is treated as an operating lease for accounting purposes (with the attendant off-balance sheet treatment) and as a loan for tax purposes (with the tax benefits of facility ownership retained by the producer). The lessee sells the facility to a special purpose vehicle that is typically funded by three lenders in certain specified proportions. The lessee then takes a lease from the special purpose vehicle and a section 16.1 election is made by the parties. There will be a residual value guarantee by the lessee with respect to the facility. A purchase option to the lessee may be provided, but it is not a bargain purchase option. A typical "ABC" structure of a synthetic lease would be as follows:

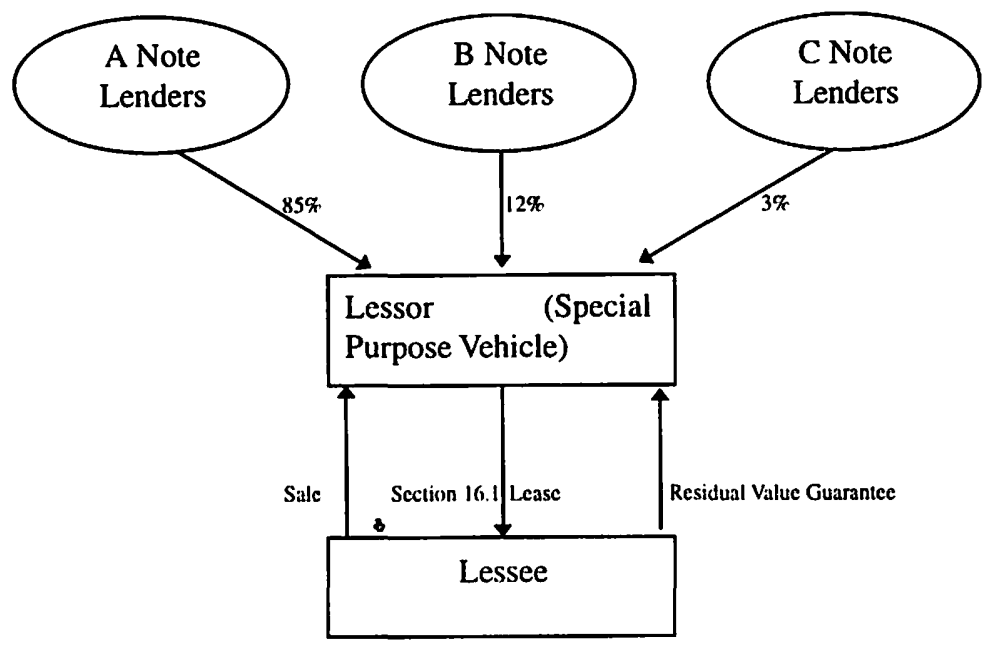

\section{B. Midstream Company Transaction Structures}

Transactions involving Midstream Companies are equally innovative as the financing structures described above, but their structures are easier to describe.

\section{Direct CASh SALE}

This kind of transaction, which is probably the most common type used by Midstream Companies, involves a purchase of the facility for cash. The producer enters into an agreement for the gathering and processing of its gas at the facility. For the producer, this is a simple process, usually producing the maximum up-front cash and allowing for a simple bidding-type sale process. The producer has no future responsibility for the operation of the facility. It may have negative tax impacts and the producer loses control of the facility operations.

s This diagram is based on a presentation and materials from $R$. Concepcion of Bay-Front Associates, "Utilizing Synthetic Leasing for Midstream Assets" (Insight Information Co. Seminar, "Effectively Managing Investments in Gas Processing Assets," 28-29 January 1999) [unpublished]. 
A Midstream Company entering into a transaction of this type gains maximum control over the operation. However, bidding situations have led to excessive purchase prices in some situations. Also, there is limited opportunity to create an innovative or customized transaction involving the producer.

\section{CASH SALE WITH INCENTIVE}

This transaction is similar to the cash sale but the Midstream Company offers additional payments to the producer if the facility or adjoining lands attains certain performance platforms, usually involving facility throughput or financial performance, new reserves added, or new well performance. The producer benefits by obtaining some of the financial benefit that it would have received as a facility owner if the performance goals had been attained without a sale of the facility.

\section{OPERATING COST GuARANTEE}

In an "operating cost guarantee" transaction, the facility is transferred to the Midstream Company for nominal consideration. The Midstream Company commits to control operating costs of the facility, usually on a fixed cost per unit of gas, although fixed and variable cost commitments are sometimes made. The producer benefits from the guaranteed operating cost (often less than current costs and without the risk of cost inflation) but does not receive any capital payment for the facility. The Midstream Company benefits if it is able to exceed the performance requirements of the operating cost guarantee but it must bear the risk of failing to meet the guarantee.

\section{EARN-IN}

The "earn-in" is an innovative transaction in which the Midstream Company earns an interest in a facility by spending capital dollars to improve the facility and expand it where required, and by increasing throughputs and diluting fixed costs. The facility is appraised and the Midstream Company earns fractional ownership based on capital spent and earnings contributed by additional activities. The charges to the producer may be based on a fixed capital fee plus a pass-through of operating costs, or an operating cost pass-through only, or a market-based fee for both operating and capital costs.

\section{OTHER STRUCTURES}

There are many other structures as well, some of them involving hybrids of the transactions listed above.

\section{AGReement ISSUES}

As discussed above, the Canadian tradition of midstream ownership has been that producers own the gathering and processing facilities associated with their own equity gas production. A consequence of this tradition is that the agreements that have been widely adopted for midstream activities have not included provisions that would easily allow for transactions involving midstream entities who acquire interests in midstream 
assets without acquiring equity interests in the gas producing lands. This means that implementing a midstream transaction of one of the types described above often entails difficulties with existing documents that govern the facilities. When commenting on what the most significant barriers to reaching a timely and successful conclusion to a midstream deal, an executive of one midstream company once said, "First, the CO\&O agreement; second, the CO\&O agreement; and third, the CO\&O agreement."

There are four fundamental agreements that are involved in most midstream transactions: the asset purchase agreement pursuant to which the midstream facility is transferred from the producer to the midstream entity; the gas gathering and processing agreement between the producer and the midstream entity; the management agreement between the producer and the Financing Party; and the Construction, Ownership and Operation Agreement ("CO\&O Agreement") among the owners of the facility which governs the co-ownership and operation issues in a facility with multiple owners.

Not all of these agreements will be necessary for each type of transaction. If the facility is to be constructed as part of the transaction, then an asset purchase agreement is not required (but a construction agreement of some type may be necessary in its place). If a Midstream Company is involved in operating the facility, then a management agreement is not necessary. If the facility is owned 100 percent by the producer, then there will not be a CO\&O Agreement with all of its attendant problems.

Following is a discussion of each of these agreements, addressing the issues that make them unique for midstream transactions. This article is not intended to discuss the multitude of issues that arise in asset purchase agreements, gathering and processing agreements, management agreements, and CO\&O Agreements that apply to all transactions; rather, the focus is on the issues involving midstream entities. Also, the comments which follow are intended to identify issues that are relevant to the interests of producers, midstream entities, and other co-owners of the facilities.

\section{A. ASSet Purchase Agreement for Midstream facilities}

Most of the issues involved in a typical purchase of a processing facility will apply to a midstream transaction without any special or unusual revisions. Unlike a Midstream Company, a Financing Party may be particularly concerned about environmental indemnities owing to its unwillingness to accept any of the risk associated with asset ownership. All midstream entities will have particular interest in the producer's reserves because that is what supports the long-term payment obligations that the producer has under the processing agreement.

In traditional upstream oil and gas asset transactions, it is common practice that the vendor does not warrant title to its assets. The grounds for this position relate to some inherent uncertainties regarding mineral title in Alberta, owing to the restrictions in our title registration system and issues under the Land Titles Act. $^{6}$ It is not unusual to have the same warranty limitation apply to tangible facilities such as gathering and 
processing facilities. However, the only assets that can be justifiably so limited are subsurface mineral rights, not tangible facilities. For this reason, title warranties are often given in relation to midstream facilities.

Rights of first refusal issues that arise as part of the midstream transaction are discussed below under the rubric of CO\&O Agreements.

\section{B. Gathering and Processing Agreements}

The gathering and processing agreement is the key new agreement entered into between the midstream entity and the producer. It establishes the long-term gas supply, gathering, and processing obligations of both parties. The producer wants to ensure that it has capacity at the facility. The midstream entity needs the commitment of the producer to deliver gas to the facility, to dedicate its reserves, and to pay the processing fees.

In some cases, the processing arrangement between the producer and the midstream entity is not established by a processing agreement, but rather by a transfer to the producer of the midstream entity's processing rights under the CO\&O Agreement. This kind of agreement is more rare and addresses many of the same issues as a processing agreement; therefore, it will not be addressed separately here.

There are many types of processing agreements in use in Canada. The Petroleum Joint Venture Association has created a model "Gas Processing Agreement," the most recent version of which was adopted in 1996. The following are the issues that arise under gas processing agreements that are unique to midstream transactions.

\section{PROCESSING FEES}

The processing fee terms are a negotiated feature of the midstream transaction that can vary widely from typical industry fees involving a fixed fee and a variable fee. Transactions involving Financing Parties are often structured more akin to loan arrangements and may involve fixed payments or take-or-pay terms. If additional capital requirements must be met, the fee may be adjusted to take those into account.

The fee arrangements are determined in large part by the type of midstream transaction being utilized. Midstream Companies and Financing Parties have very different needs and requirements, as should be apparent when reviewing the many transaction structures described above. Where a Midstream Company might be prepared to give an operating cost guarantee, the Financing Party will want the opposite - a covenant on the part of the producer to pay all of the operating costs.

\section{RESERVES DEDICATION AND COVENANT TO DELIVER}

In most processing agreements involving firm processing obligations, whether or not a midstream entity owns the facility, the producer gives a commitment that all its gas produced from specified lands will be delivered to the facility. The dedication may be 
either a commitment of reserves in situ or a promise by the producer to deliver production from a certain area. In the case of transactions involving midstream entities, especially Financing Parties, this may be accompanied by a commitment to produce and deliver gas from specified lands.

The dedication of lands sometimes raises the issue of whether the midstream entity has acquired an interest in the lands that "runs with the lands" and is capable of registration. There is no case law directly on this subject, but if an analogy is made to cases involving gross overriding royalties, it seems unlikely that a mere commitment to deliver gas from certain lands would qualify as an interest in land. Nevertheless, the parties should ensure that any negative covenants with the producer's lender are neither breached nor waived as part of the transaction.

\section{CAPACITY}

Both the midstream entity and the producer want to ensure that there is capacity for the producer's gas at the facility. The midstream entity will be looking for a long-term capacity commitment or reservation. A failure to fulfill the capacity commitment or a decision to reduce its capacity obligation will trigger an obligation to pay the midstream entity. The producer will want to have the ability to alter its capacity obligations over time, either increasing them or decreasing them as the occasion requires. The producer will also want to have a right of first refusal on any additional capacity that the midstream entity wishes to contract on a firm basis to other parties.

\section{EXPANSION}

The potential for expansion of the facility is an issue that is critical to both parties. Midstream Companies are highly motivated to enhance facility throughput and want to ensure that they have expansion rights. Producers want to know that any new production that they might discover in the area will be processed at the facility. The ability to control facility expansion is one of the issues that has motivated producers to own their processing capacity rather than contract it out to midstream entities.

Midstream Companies tend to be more flexible in these matters than Financing Parties, who are quite willing to see additional production in the area, which enhances their "security", but may not be anxious to advance additional funds. Often a renegotiation of the midstream transaction is necessary.

A related issue is the right of the producer to process its gas at some other facility if the contracted facility is full. A producer will want to ensure that its freedom to get its gas on stream is not unduly restricted by the processing agreement.

\section{INDEMNITY}

Midstream Companies and Financing Parties take different approaches to indemnity issues. A Financing Party will want a complete indemnity by the producer for all 
activities related to the facility. A Midstream Company is more willing to accept the business risks associated with the ownership and operation of the facility.

\section{OTHER FEATURES}

Financing Parties often look for other terms in their processing agreements that tend to make the agreement look more like a security or lending document than a traditional processing agreement. These may include: financial, production, and reserve reporting requirements; covenants regarding payment of taxes and other obligations necessary to carry on business; and default provisions that entitle acceleration in the event of default or the failure to meet certain financial tests.

\section{Management Agreements}

Where the midstream transaction involves a Financing Party who does not wish to have operational control of the facility, it is common to have a facility management agreement (sometimes known as a contract operating agreement) which gives operational control over day-to-day matters to the producer. It may also include indemnification of the Financing Party with respect to operational matters.

\section{CO\&O Agreements}

Most oil and gas operations in Canada today are owned by more than one company. Co-ownership of oil and gas producing interests and facilities results in complicated arrangements to govern co-owned operations.

The unique feature of midstream transactions is that it creates two classes of owners in a facility: those who own the upstream producing lands and those who do not. There are a number of fundamental issues that are shared by co-owners of the producing lands and which are not shared by a person whose only interest is in the facility. Separation of ownership creates inherent conflicts. This is the reason for the frequent problems that arise when dealing with CO\&O Agreements in the context of a midstream transaction.

The issues arise under practically all CO\&O Agreements in common use in industry today. For the purposes of this review, the provisions of the Petroleum Joint Venture Association's 1996 model form Agreement for Construction, Ownership and Operation (the "PJVA Model CO\&O Agreement") will be examined.

\section{OWNER'S SUBSTANCES}

One of the most important issues is the definition of "Owner's Substances." This key term defines the substances that receive priority treatment under the CO\&O Agreement. In the PJVA Model CO\&O Agreement, this term is not explicitly defined, permitting the parties to develop their own definition of this important term. However, the annotations to the PJVA Model CO\&O Agreement suggests the following definition: 
"Owner's Substances" means an Owner's production from any well that is located in the Preferential Area and meets the specifications set out in the Appendix entitled "SPECIFICATIONS OF INLET SUBSTANCES AND FACILITY PRODUCTS".'

Other definitions that have been used in some CO\&O Agreements include the following:

- "Owner's Gas" means natural gas owned by an Owner upstream of the Facility.

- "Owner's Designated Gas" means Gas owned by, and produced from mineral interests owned by, an Owner and within the Designated Area, before it has been subjected to processing, including all Plant Products and excluding such portion as is lost or consumed as Fuel Gas.

In each case, these provisions do not adequately deal with a Financing Party or a Midstream Company who does not own gas upstream of the facility. In these cases, revisions are necessary to the CO\&O Agreement. One example would be:

"Owner's Designated Gas" means Gas owned by and produced from mineral interests owned by an Owner and within the Designated Area, but also includes gas produced by <Producer $>$ or any successor in interest to <Producer $>$ from the Designated Area, before it has been subjected to processing, including all Plant Products and excluding such portion as is lost or consumed as Fuel Gas.

Another example, using the PJVA Model CO\&O Agreement as a basis, is:

“Owner's Substances" means an Owner's production from any well that is located in the Preferential Area and meets the specifications set out in the Appendix entitled "SPECIFICATIONS OF INLET SUBSTANCES AND FACILITY PRODUCTS," or where an Owner is a bona fide Financing Party, for the duration of the financing arrangement, that working interest production from the wells, current and future, owned and produced by that previous Owner which transferred its interest to that Financing Party and which meets the specifications described above.

The annotations to the PJVA Model CO\&O Agreement contains the following admonition regarding third party production to be processed as "Owner's Substances":

If a specific Agreement is negotiated to include third party (non-Owner) production as part of defined "Owner's Substances" then the parties should be aware that this will impact on other provisions in this Agreement; particularly the Capacity Usage Appendix. An Owner who would carry a non-Owner's production through the Facility as part of "Owner's Substances" may be assuming certain responsibilities and risks; particularly in the areas of: product allocation, re-allocation of Operating 
Costs, sharing of liabilities, settlement of disputes and carrying insurance. The Owner may require some type of carried interest agreement with non-Owner. After weighing these responsibilities and risks, the right decision is usually to bring the proposed third party owner of production into the Facility Agreement as an Owner. ${ }^{8}$

Similar issues of defining "substances" arise when the CO\&O Agreement creates multiple classes of gas that receive differing levels of priority under the agreement. It is not uncommon to have definitions of "Owner's Gas," "Owner's Outside Gas," and "Outside Gas," with access priority given to those categories in that order. The definition of "Owner's Outside Gas" must be addressed in the same way as the "Owner's Gas" issue as discussed above, otherwise a Financing Party or Midstream Company may find that it has only the lowest priority of access.

Amendments to the "substances" definitions will work well in situations where a new CO\&O Agreement is being developed or where the situation allows parties to an existing CO\&O Agreement to discuss and make amendments. However, there are many situations where a Financing Party or Midstream Company steps into an existing CO\&O Agreement without the opportunity or leverage to be able to make amendments to the agreement. In this situation, there are some steps that may be considered as options.

The first option is to create a "buy-sell" situation so that the Midstream Company who does not own the producing mineral interests nevertheless becomes the owner of the gas upstream of the facility. The Midstream Company then gathers and processes the gas through the facility with all the priority normally accorded to "Owner's Gas" and then re-sells that gas to the producer immediately downstream of the facility. The Midstream Company earns its "fee" by the differential between the negotiated purchase price and re-sale price.

This structure works well in situations where the definition of "Owner's Gas" (or its substitute) does not disallow it. Certain definitions of "Owner's Gas" would not give any priority to gas acquired by a Midstream Company pursuant to a buy-sell arrangement. For example, one of the sample definitions above defines "Owner's Gas" as gas which is "owned by, and produced from mineral interests owned by, an Owner." This definition seems to make it clear that only a person with subsurface interests could have "Owner's Gas." On the other hand, the definition that states that "Owner's Gas" is gas owned by an owner upstream of the facility would appear to permit a buy-sell arrangement because the mere ownership of gas, as opposed to the ownership of the lands from which the gas was produced, is sufficient to meet the requirements of the definition. The availability of this option must be considered in each case.

Another option that probably works under any type of CO\&O Agreement involves the transfer to the Financing Party or the Midstream Company of the entire working interest of the producer in the midstream assets and the producing lands. The Financing Party or Midstream Company then grants a 99 percent net royalty in the acquired 
assets, so the producer receives essentially all of the net revenue that it would otherwise have received had it continued to own the interests. It also achieves the desired result under the CO\&O Agreement because the gas flowing through the facility truly is "Owner's Gas." This structure is similar to that used for many royalty trusts. However, there are tax consequences of such a transaction that may not be attractive to the producer.

Other options include the use of general or limited partnerships in such a way as to create an argument that the midstream assets, or the producing lands, or both, have either not been conveyed such that the producer still owns them, or have all been conveyed, such that the partnership owns both the midstream assets and the producing lands.

\section{CAPACITY USAGE}

Capacity usage provisions are of critical importance to the owner of a facility, whether a producer, Financing Party, or Midstream Company. However, these issues are usually addressed as part of the definition of the "substances" which are the subject of the CO\&O Agreement.

The more important issue that may need to be addressed is the sharing of any fees payable in connection with the processing of "Outside Gas." If surplus capacity is available in the facility and is utilized by a party for the processing of "Outside Gas," the CO\&O Agreement may require the sharing of the fees associated with that "Outside Gas" among all of the co-owners of the facility. If such a provision exists, this is the reason to ensure that the producer's gas is not going to be treated as "Outside Gas" because then the Midstream Entity's intended revenue stream will have to be shared among all facility owners.

Midstream Companies may have a greater concern about such provisions. It is their goal to try to use their marketing capabilities to increase gas throughput at the facility. It is also their strong preference to see the benefits of this additional throughput to flow principally to them. However, many CO\&O Agreements do not adopt this "competitive" approach to the use of plant capacity. Indeed, this is one area where the attitude of producer co-owners often differs from that of Midstream Companies.

\section{REPLACEMENT OF OPERATOR}

The PJVA Model CO\&O Agreement, and most other CO\&O Agreements, provide that the operator is removed if it ceases to be an owner of the facility. ${ }^{9}$ This is one of the most intractable provisions of the agreement. It clearly requires amendment if the transaction involves a Financing Party who does not intend to operate the facility but intends to permit the producer to continue to operate the facility. This situation creates

9 For example, in the PJVA Model CO\&O Agreement, Clause 303 of the Operating Procedure provides in part as follows: "303 ... Operator shall also be replaced at the time determined pursuant to Clause 304 if: ... (d) Operator ceases to be an Owner.... " 
a separation of ownership and operation which the CO\&O Agreement appears to prohibit. However, from the point of view of the other owners of the facility, there is essentially no change in the actual conduct of operations; the producer/operator's gas still flows through the facility and the producer/operator continues to operate.

One solution often used by Financing Parties and producers in this situation is to have the producer act as the contract operator under the agreement. ${ }^{10}$ This will be satisfactory where the mere assignment of the producer's interest to the Financing Party still permits the Financing Party to be the designated operator. It is important to remember that operatorship is not an assignable right, so the role of the producer can only be as a subcontractor. When the owner who happens to be the operator sells its interest, which occurs in essentially any midstream transaction involving a Midstream Company or a Financing Party, its resignation follows. The CO\&O Agreement then provides for an election for a new Operator. If the interest of the producer who is resigning is sufficiently large, the Financing Party or Midstream Company will be able to ensure its re-election as Operator and the producer can be hired as contract operator. However, there are some situations where the resignation of the operator as part of a midstream transaction creates an opportunity that another owner may want to seize to try to become operator. For this reason, producers often want to avoid the very issue of resignation as part of a midstream transaction.

If the transaction involves a Midstream Company who intends to become the true operator without any subcontracting arrangement with the producer, then the process of voting for a replacement operator as contemplated by a CO\&O Agreement is quite appropriate. The owners should have the right to decide who should be the operator of their facility, and a Midstream Company may represent a material change from the style of operation with which the owners are familiar. The Midstream Company should have the opportunity to put its best foot forward, but also should recognize that one of the features of co-ownership is the right of the co-owners to determine who among them is to operate the facility.

The situation is different where the midstream transaction involves a Financing Party who has no plans to operate the facility but who intends to have the producer continue to operate. The other owners will see no functional difference in the conduct of activities at the facility. A modern and sophisticated CO\&O Agreement should allow for a midstream transaction of this type with a simple notice and consent procedure. Moreover, the consent procedure should only provide limited grounds for refusing consent because the transaction will not introduce material operational changes at the facility. If the producer is not in default of its obligations under the CO\&O Agreement and the Financing Party has adequate financial wherewithal, consent should follow.

10 Clause 401 of the PJVA Model CO\&O Agreement provides in part that, "401... Operator shall conduct and oversee all Joint Operations, and in particular shall: ... (i) subject to Clause 402, subcontract such portion of Joint Operations as Operator deems appropriate" [emphasis added]. However, some CO\&O Agreements require the approval of the Operating Committee for any subcontracting arrangements. 


\section{DISPOSAL OF FACILITY INTEREST}

Transfer restrictions are another major area of concern in midstream transactions. Issues arise on both the initial establishment of the transaction and on any subsequent re-sale to the producer pursuant to the repurchase option that may have been created.

The PJVA Model CO\&O Agreement is possibly the most "modern" common CO\&O Agreement. This issue is important enough to justify including the majority of its provisions relating to transfer.

\section{Disposal of an Interest in the Facility}

Except as provided in this Article IX, no Owner shall sell, transfer, assign, mortgage or otherwise dispose of all or part of its interest in the Facility or any Functional Unit. An Owner who intends to dispose of all or a part of its interest in the Facility or any Functional Unit (in this Article called "the Disposing Owner") shall comply with the provisions of ALTERNATE, immediately below:

ALTERNATE A. The Disposing Owner shall be under no obligation to obtain the consent of the other Owners or to provide the other Owners with a right to acquire that Disposing Owner's interest in the Facility.

ALTERNATE B. The Disposing Owner shall obtain the consent of the other Owners, and shall provide them with information regarding the disposition, including the description of the Functional Unit Participation proposed to be disposed and the identity of the proposed assignee. Such consent shall not be unreasonably withheld, and it shall be reasonable for an Owner to withhold its consent to the disposition if it reasonably believes that the disposition would be likely to have a material adverse effect on it, its Functional Unit Participation or Joint Operations, including, without limiting the generality of all or any part of the foregoing, a reasonable belief that the proposed assignee does not have the financial capability to meet prospective obligations arising out of this Agreement, provided that an Owner which withholds its consent shall include in its notice its reasons for withholding consent. However, an Owner shall be deemed to have consented to the disposition to the proposed assignee, unless, within twenty (20) Days, the Owner advises the other Owners, by notice, that it is not prepared to consent to such disposition.

ALTERNATE C. (a) The Disposing Owner shall, by notice, advise each other Owner (in this Article called an "Offeree") of its intention to make the disposition, including in such notice a description of the Functional Unit Participation proposed to be disposed, the identity of the proposed assignee, the price or other consideration for which the Disposing Owner is prepared to make such disposition, the proposed effective date and closing date of the transaction and any other information respecting the transaction which the Disposing Owner reasonably believes would be material to the exercise of the Offerees' rights hereunder (such notice in this Article called "the Disposition Notice").

(b) If the consideration described in the Disposition Notice cannot be matched in kind and the Disposition Notice does not include the Disposing Owner's bona fide estimate of the value, in cash, of such consideration, an Offeree may, within seven (7) Days of the receipt by the Offerees of the Disposition Notice, request the Disposing Owner to provide such estimate to the Offerees, whereupon 
the Disposing Owner shall provide such estimate in a timely manner and the election period provided herein to the Offerees shall be suspended until such estimate is received by the Offerees.

(c) If there is a dispute as to the reasonableness of an estimate of the cash value of the consideration described in the Disposition Notice or provided pursuant to Subclause (b), as the case may be, the matter shall be referred directly to arbitration under the Appendix titled "DISPUTE RESOLUTION" within seven (7) Days of the receipt of such estimate. The Disposing Owner and the applicable Offeree shall thereupon diligently attempt to complete such arbitration in a timely manner. The equivalent cash consideration determined in such arbitration shall thereupon be deemed to be the sale price for the Functional Unit Participation described in the Disposition Notice.

(d) Within the later of i) thirty (30) Days from the receipt of the Disposition Notice, as modified by any suspension pursuant to Subclause (b) of this Alternate C; or ii), if Subclause (c) of this Alternate $C$ is applicable, fifteen (15) Days from receipt of notice of the arbitrated value determined pursuant to the preceding Subclause, an Offeree may give notice to the Disposing Owner that it elects to purchase the Functional Unit Participation described in the Disposition Notice for the applicable price (in this Article called a "Notice of Acceptance"). A Notice of Acceptance shall create a binding contractual obligation upon the Disposing Owner to sell, and upon an Offeree giving a Notice of Acceptance to purchase, for the applicable price, all of the Functional Unit Participation included in such Disposition Notice on the terms and conditions set forth in the Disposition Notice. However, if more than one Offeree gives a Notice of Acceptance, each such Offeree shall purchase the Functional Unit Participation to which such Notice of Acceptance pertains in the proportion its Functional Unit Participation bears to the total Functional Unit Participation of all such Offerees.

(e) If the Functional Unit Participation described in the Disposition Notice is not disposed of to one or more of the Offerees pursuant to the preceding Subclause, the disposition to the proposed assignee shall be subject to the consent of the Offerees. Such consent shall not be unreasonably withheld, and it shall be reasonable for an Offeree to withhold its consent to the disposition if it reasonably believes that the disposition would be likely to have a material adverse effect on it, its Functional Unit Participation or Joint Operations, including, without limiting the generality of all or any part of the foregoing, a reasonable belief that the proposed assignee does not have the financial capability to meet prospective obligations arising out of this Agreement, provided that an Owner which withholds its consent shall include its reasons for withholding consent in its notice. However, an Offeree shall be deemed to have consented to the disposition to the proposed assignee, unless, within the time period prescribed in Subclause (d), the Offeree advises the other Owners, by notice, that it is not prepared to consent to such disposition.

(f) If the Functional Unit Participation described in the Disposition Notice is not disposed of to one or more of the Offerees pursuant to Subclause (d) of this Alternate C, the Disposing Owner may, subject to obtaining the consents prescribed by the preceding Subclause, dispose of such Functional Unit Participation at any time within one hundred and fifty (150) Days from the issuance of such Disposition Notice, provided that such disposition is not on the terms that are more favourable to such proposed assignee than those offered in the Disposition Notice.

(g) Following a disposition herein or one hundred and fifty (150) Days following the issuance of a Disposition Notice from which a disposition did not result, as the case may be, the provisions of this 
Clause 901 shall once again apply to the Functional Unit Participation described in the Disposition Notice.

\section{Unrestricted Disposals}

Notwithstanding anything contained in this Article IX, an Owner may transfer all or a portion of its interest in the Facility without providing prior notice or the option to acquire such interest to the other Owners in the following instances, namely:

(a) a disposition to an Affiliate of the Owner, or in consequence of a merger or amalgamation of the Owner with another corporation or pursuant to an assignment, sale or disposition made by an Owner of its entire Facility Participation to a corporation in return for shares in that corporation or to a registered partnership in return for an interest in that partnership;

(b) if a portion of an Owner's interest in the Facility is disposed of as a result of the conversion of a gross overriding royalty interest or other interest to a working interest in a well pursuant to an agreement in existence as of the Effective Date, and the production from such well is required to be delivered to the Facility;

(c) a disposition made by an Owner of all, or substantially all, or of an undivided interest in all or substantially all, of its petroleum and natural gas rights in the province or territory where the Facility is situated, and for the purposes of this Subclause, "substantially all" means a percentage of ninety percent $(90 \%)$ or more of the net hectares held by such Owner in that province or territory; and

(d) Subclause (d) shall /shall not apply:

a disposition made by an Owner of all, or substantially all, or of an undivided interest in all or substantially all, of its petroleum and natural gas rights in wells producing to the Facility.

However, an Owner making such a disposition pursuant to Subclause (a), (b), (c) or (d) of this Clause shall advise the Operator of such disposition in a timely manner, and shall comply with the provisions of Clause 905.

If the transfer is to an Affiliate, the Owner shall execute and deliver to Operator a continuing guarantee of all obligations to be assumed by the Affiliate under this Agreement. Such guarantee shall also provide that the guarantor waives notice of any extensions, modifications or amendments to this Agreement and agrees to be bound thereby; that no such extensions, modifications or amendments will release the guarantor; and that the guarantor will not be relcased by any waiver of any obligation of the Affiliate by the indulgence or concession granted to it.

\section{Financing}

Notwithstanding anything contained in this Article IX:

(a) An Owner may mortgage its interest in the Facility; provided that any such mortgage shall expressly provide that the mortgagee shall hold the interest subject to all the terms and provisions of this Agreement, and shall also provide that upon any realization of the security, the party acquiring the 
interest in the Facility shall be required to assume all obligations of the morgagor under this Agreement, including the obligations imposed under Clause 905; and

(b) An Owner may assign its interest in the Facility to one or more financial institutions in connection with an arrangement for the financing of its interest in the Initial Construction of the Facility provided that:

(i) any such assignment shall expressly provide that the assignee shall hold the interest subject to all the terms and provisions of this Agreement;

(ii) until the assignee gives notice to Operator of a default by the assignor under the arrangement for financing and complies with the provisions of Clause 905, the assignor shall not be released from its obligations under this Agreement, shall remain an Owner for the purposes of Exhibit " $A$ ", under the Appendix titled "FACILITY AND FUNCTIONAL UNIT PARTICIPATION", and the Owners shall be entitled to deal exclusively with the assignor in all matters under this Agreement;

(iii) until the assignee gives notice to Operator of a default by the assignor under the arrangement for financing and complies with the provisions of Clause 905 , the assignor shall have full power and authority to act on behalf of and bind the assignee for all matters respecting this Agreement, and any information, notices or bilings served on or by, or any payment to the assignor shall be deemed to have been served on or by or payment made to the assignee and the other Owners shall neither honour notices from nor give notices to the assignee; and

(iv) any such assignment shall expressly provide that immediately upon receipt by the Operator of notice from the assignee that the assignor is in default under the arrangement for financing, realization of the security or otherwise, the assignee shall be required to assume all obligations of the assignor under this Agreement."

Clause 901 provides three optional provisions to deal with dispositions: an absolute right to dispose, a consent right to the non-assigning parties, and a right of first refusal. It is common in many CO\&O Agreements to have a right of first refusal. This poses some difficulty for midstream transactions because the nature of the transaction is usually unique. It is not simply a choice by the producer to sell its interest in the facility. Rather, it is a choice either (i) to enter into a financing arrangement not dissimilar from a loan transaction, in the case of a midstream transaction involving a Financing Party; or (ii) to involve a Midstream Company with particular gas gathering and processing expertise and focus. An exercise of a right of first refusal in which one of the other facility owners steps into the shoes of the Financing Party or Midstream Company is unlikely to be a satisfactory outcome for the producer. It does not want a co-owner of the facility to be its "lender," and it probably does not want the co-owner to be the processor of its gas, although there may be less concern about that situation.

A related issue is the selling price of the facility. Midstream transactions are essentially negotiated transactions where there are mutual payment covenants. The Midstream Company or Financing Party makes a payment to the producer representing 
the purchase price of the facility, and the producer makes continuing payments in return representing processing fees. The purchase price of the facility is quite negotiable so far as all parties are concerned because there is a counterbalancing payment of processing fees. Accordingly, the purchase price may not necessarily represent "fair market value" to some other independent buyer or seller. However, that cash price probably is a fair market value because it represents the mutually agreed price for the facility between two parties who presumably are at arm's length.

The consent provision of the PJVA Model CO\&O Agreement is circumscribed by requiring that consent not be unreasonably withheld and by establishing some of the criteria and grounds that would be necessary for consent to be refused. These provisions codify obligations which may already exist at law. Co-owners of facilities should consider carefully any decision not to consent to a transaction because the courts have shown the willingness to override such decisions when not properly made. For example, in Zurich Canadian Holdings v. Questar Exploration, ${ }^{12}$ a refusal to give consent when given without any reasons was held to be unreasonable. ${ }^{13}$

One provision of the transfer process for midstream transactions where co-owners will want to receive assurances is the question of dedication of lands. If the assigning producer has dedicated lands and production to be delivered to the facility, the coowners will want to know that the producer has made a similar commitment to the midstream entity. However, this is unlikely to be a problem because the midstream entity will want to have that same assurance as well, probably as part of the gas processing agreement.

As indicated above, some CO\&O Agreements require that the producer dedicate its interests in the producing lands to the facility. Where a new party does not have any producing land in the area, it may be that there are reasonable grounds for refusing to consent to the transaction. However, if the midstream transaction involves a processing arrangement that commits the producer's gas to the facility, it is doubtful that other coowners of the facility are harmed by the change, although they lack the contractual privity with the producer who has given the dedication under the processing agreement.

Subclause 902(d) is an interesting election provision of the PJVA Model CO\&O Agreement. It permits the parties to include a provision that waives compliance with the assignment restrictions if the upstream interests associated with the facility are also being assigned. Older CO\&O Agreements commonly included such a provision so as not to create conflicts between rights of first refusal that apply to facilities and upstream interests. Such conflicts would have the potential of preventing the transfer of upstream facilities because of midstream assignment restrictions.

A related provision that appears in some CO\&O Agreements, but not in the PJVA Model CO\&O Agreement, is an absolute prohibition on the transfer of the facility without the associated transfer of the upstream producing interests. This can effectively

See also Cudmore v. Petro-Canada, [1986] 4 W.W.R. 38 (B.C.S.C.). 
stymie a midstream transaction, giving to each of the other facility owners an absolute right of consent to the transfer, probably without any requirement that it act reasonably in doing so. Only some of the more innovative structures described above might allow a midstream transaction to occur without co-owner consent in the face of a clause such as this.

Clause 903 of the PJVA Model CO\&O Agreement contains exceptions to the transfer restrictions for mortgages and other similar types of traditional financing arrangements. It also includes provisions dealing with transfers associated with construction financing. These provisions are not broad enough to address the issues of typical midstream transactions of the types described above that involve Financing Parties. However, any transactions that do not involve the transfer of an interest in the facility should be covered by this clause.

A case can be made that typical CO\&O Agreements should be altered to allow for midstream transactions involving Financing Parties to occur without a right of first refusal or other transfer restrictions. These transactions are not all that dissimilar in their concrete operational impact than a traditional mortgage financing, which is widely permitted without any consent requirement. The basis for most transfer restrictions is to give to the other co-owners the right to choose their "partners" in the facility. To the extent that a midstream deal which involves a Financing Party, but where the producer continues to have operational control, effects no change to facility activities, there is little basis for justifying the transfer restrictions in the agreement. This comment is probably not the same for midstream deals with Midstream Companies. Real operational change can occur in such circumstances so the right to consent or not may be more suitable there.

Most midstream transactions involving Financing Parties also involve a right on the part of the producer to repurchase the facility. The transfer restrictions of the CO\&O Agreement will also apply to this transaction unless the parties have made some other arrangements. Once again, there is little ground for granting to co-owners the right to consent or exercise a right of first refusal on the re-transfer of the facility interest to the original producer. If the CO\&O Agreement cannot be amended to address this issue, the next best approach is to obtain consent to both the initial transfer and the subsequent reconveyance as part of the initial consent of the co-owners. This is especially important because the reconveyance may be for a nominal amount, so a right of first refusal may be exercisable at a desirable price. The reconveyance right is a key term of the transaction for the producer, and it will want to ensure that it does not lose its processing rights at the end of the term of the midstream arrangement.

Another kind of transfer restriction that appears in some CO\&O Agreements is a provision entitling the operating committee established under the CO\&O Agreement to approve any transfer of interest in the facility and to impose conditions on the transfer. This type of restriction, which is rarer than the other transfer restrictions discussed above, may work well to establish some reasonable transfer requirements, such as the existence of dedication provisions from the producer as part of the midstream transaction. 


\section{Disposition OF FACILITY Products}

Just as is the case with joint operating agreements, CO\&O Agreements generally establish that each party has the right to take in kind its share of facility products. When a midstream transaction is entered into, it is typical for the producer to continue to have the obligation to take in kind its share of facility products. In fact, producers will insist on it, especially in the case of transactions involving Financing Parties. Similarly, the Financing Party will want the producer to handle product sale issues because it is not qualified to handle such matters. This will typically be addressed in the processing agreement.

Midstream Companies in many cases are involved in the marketing of production as a separate part of their business, and they may be prepared to make product marketing part of their business arrangement with the producer.

Take-in-kind issues are a matter that this author has addressed before, ${ }^{14}$ and there are many situations where problems can still arise. However, in recent years it has become much more common for all parties involved in a joint operation to handle the marketing of their own production and major take-in-kind issues are rare. The current approach to these issues is a result in part of the decision in Erehwon Exploration v. Northstar Energy, ${ }^{15}$ where Hunt J. (as she then was) held that the operator did not have fiduciary obligations related to the marketing of gas under an agreement that adopted the Canadian Association of Petroleum Landmen 1981 Operating Procedure.

The consequence of these circumstances is that the take-in-kind provisions of the CO\&O Agreement deserve attention in the context of a midstream transaction, although it is not likely that changes will be required in the normal situation.

Some questions have arisen about the relative priority of the take-in-kind provisions of a CO\&O Agreement and those of the operating agreement governing jointly owned lands.

\section{OPERATOR'S LIEN}

All CO\&O Agreements create a lien in favour of the operator for each owner's share of the costs of the joint operation. When a midstream transaction is entered into, a new relationship is established between the producer and the Financing Party or the Midstream Company, as the case may be. The set-off provisions of that lien should also apply to the financial relationship of the producer and the Financing Party or Midstream Company. The operator of the facility may have other agreements with the producer that it may wish to have available for set-off purposes, and the midstream transaction ends the contractual privity that would otherwise be available to it. 
Using the example of the PJVA Model CO\&O Agreement once again, this change could be effected as follows:

602. Operator's Lien

(b) If an Owner fails to pay or advance any of the costs or expenses incurred for the Joint Account which are to be paid or advance by it within the time period prescribed by the Accounting Procedure, Operator may, without limiting Operator's other rights as contained in this Agreement or otherwise held at law or in equity: . . (iii) set-off against the amount unpaid by such defaulting Owner, any sums due or accruing to such Owner (and if such Owner is a Financing Party or Midstream Company, from sums due or accruing to the Assigning Producer) from Operator in accordance with ALTERNATE _ immediately below:

ALTERNATE A pursuant to this Agreement;

ALTERNATE B pursuant to this Agreement and from any other agreement between Operator and such Owner (and if such Owner is a Financing Party or Midstream Company, pursuant to any other agreement between Operator and the Assigning Producer), whether executed before or after the Effective Date.... ${ }^{16}$

Another lien issue that deserves consideration is the question of the right of an operator to recover monies from a producer that is no longer an owner of the facility. Usually the Financing Party or Midstream Company will have lien provisions in its gas processing agreement allowing for the recovery of production sale proceeds if payment of processing fees is not received. The operator may want to have some rights in relation to those proceeds as well and perhaps should have a subrogation of the rights under that lien to protect its own operator's lien if the midstream entity does not pay.

\section{OPERATING}

Most CO\&O Agreements provide for an operating committee to have the power to make decisions about most material operational matters. As a new owner, the midstream entity will have representatives on that committee. However, if the midstream entity is a Financing Party, it will have little interest in routine operational matters and it would prefer to have the producer as its representative. The parties might consider an amendment to the membership arrangements of the operating committee that would allow the producer to participate in its activities even though it is not an owner. The arrangements between the producer and the Financing Party may provide that it has the power to vote the interest of the Financing Party on certain matters. 


\section{COMMUNICATIONS}

The parties may wish to consider adding the producer as a recipient of all notices related to facilities issues, in addition to the midstream entity.

\section{E. LENDER ARrangemEntS}

Midstream transactions involving a Financing Party are often structured with many features similar to those of a loan arrangement. Where the producer has an existing lender under a traditional lending arrangement, it may be necessary to obtain lender consent to some aspects of the midstream transaction, such as the dedication covenant or lien that is given to the Financing Party by the producer. Also, if the lender has security applicable to the midstream facility, this will need to be released as part of the transfer to the Financing Party.

\section{F. The Missing CO\&O AgReEment}

All too often the co-owners of a gas field have intended to execute a CO\&O Agreement but have failed to complete the negotiations to establish one. Situations of this type can often continue for many years. When co-ownership issues arise, as they inevitably do, the question becomes: What terms govern the relationship? While it may be possible that some or all of the unexecuted draft provisions have been accepted by the parties, it is unlikely that a court will find an unsigned agreement to be persuasive evidence of the intention of one or more parties.

It is more likely that no agreement governs. Industry practice may be a persuasive argument in some cases, but otherwise it is probably the common law that applies. The unfortunate news is that the common law has not developed anything near the sophistication of the provisions of a common CO\&O Agreement. Indeed, there is not even a concept of "operatorship" at common law, although the courts might impose fiduciary duties on someone who acts as though it were an operator.

The absence of a CO\&O Agreement is another potential show-stopper in entering into a midstream transaction. It is unlikely that a Financing Party or a Midstream Company will be willing to enter into a midstream deal without an executed CO\&O Agreement. The only proper recommendation to be made in this situation is to encourage co-owners to enter into CO\&O Agreements to govern their operations, but this is easier said than done. However, the alternative is to be tossed about on the uncertain seas of the common law pertaining to cotenancy.

\section{Conclusion}

The evolution of the midstream business in Canada has led to changing attitudes by producers towards midstream entities. However, the new business structures conflict with the terms and conditions of common midstream agreements in use throughout the industry. 
The time has come for the Canadian oil and gas industry to recognize that these standard arrangements require amendment to permit midstream transactions to occur without undue restrictions. In the case of issues arising under CO\&O Agreements, many aspects of midstream transactions have little or no impact on the interests of other coowners in the facility. There is no reason why CO\&O Agreements could not include provisions, which among other things:

- permit automatic consent to a transfer to a Financing Party that meets certain reasonable financial tests where the producer is not in default under the CO\&O Agreement;

- allow the reconveyance from a Financing Party to the producer under the repurchase option that is common in midstream transactions;

- alter the definition of "Owner's Substances" (or its equivalent term and all related terms) to include producer's gas delivered to the facility from designated lands for processing through the capacity of a midstream entity; and

- allows a producer to act as operator in place of its Financing Party.

The matters that require resolution in the case of a midstream transaction necessitate revisions to the CO\&O Agreement. In some cases, decisions of the operating committee can occur by way of mail ballots. It may seem attractive to try to make the necessary amendments in this manner. This is particularly true where there are a number of participants in the CO\&O Agreement with small interests. However, with only a few exceptions, the amendments that need to be made require changes to the CO\&O Agreement which is not a prerogative of the operating committee. Accordingly, the better view is that mail ballots have limited use in effecting the kind of changes required in $\mathrm{CO} \& \mathrm{O}$ Agreements for a midstream transaction. ${ }^{17}$

Put in the context of all the changes that have occurred in the Canadian gas business in the past fifteen years, the changing business of gas processing is hardly earthshaking. However, it is just another sign of the continuing evolution of the business and of the need for Canadian oil and gas industry documents to change with the times.

For a more detailed discussion of this issue, including an analysis of the applicability of the principle of estoppel in pais, see K.S. Stickland \& R.G. Polson, "Trouble-Shooting Gas Processing and Other Arrangements in the Context of a Structured Financing Arrangement" (Insight Information Co. Seminar, "Effectively Managing Investments in Gas Processing Assets," 28-29 January 1999) [unpublished]. 